Graphical Abstract

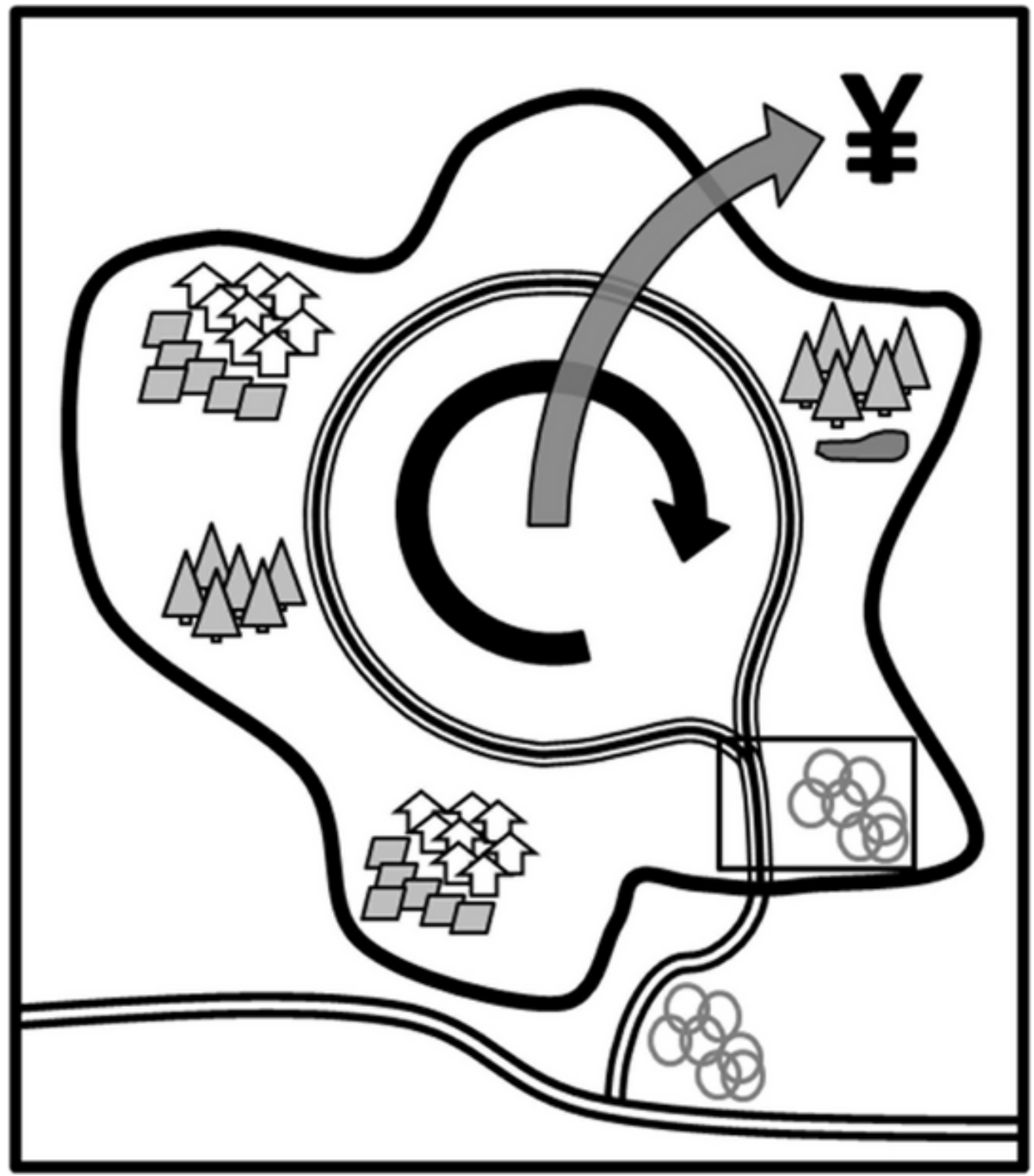




\title{
Tourism Dynamos: Selective Commodification and Developmental Conservation in China's Protected Areas
}

\author{
Abstract \\ At scenic sites across China, rural officials compelled to maximize revenue use local state \\ authority over protected areas to foster "tourism dynamos". Local states set up infrastructure \\ and institutions around rural attractions that channel the circulation of tourists, churning out \\ revenues that meet quotas and fund further expansion of attractions and towns. To make these \\ dynamos turn, local authorities have displaced resident-led tourism operations they had \\ previously helped set up. Residents are reincorporated in varying ways and often retain land \\ use rights. Meanwhile, as revenues stream out of attractions, what little is invested in \\ environmental protection goes to maintaining scenery. Local governments also accomplish \\ spatial transformations, within each park intensifying surplus generation in areas zoned for \\ tourism while reserving other areas from use, and beyond park boundaries linking attractions \\ together on tourism circuits radiating from central towns. This state-driven transformations \\ depend on how the reservation of land from commodity exchange within protected areas comes \\ together with specific state capacities to enable tourism intensification. These processes, which I \\ label "developmental conservation," call attention to selective commodifications and the \\ mediating role of the state in protected area governance in China and beyond.
}

\section{Keywords}

China; Protected Areas; Tourism; Conservation; Neoliberalization; Rural Development 


\section{Introduction}

In the last two decades, local states have turned protected areas across China into high-volume tourism attractions. Where previously rural residents led tours and accommodated visitors, or vehicles from outside vied for space on rough roads, now thousands of visitors arrive daily to board buses or cable-cars that shuttle them to scenic spots. These systems enable thousands to tour an attraction daily, yielding substantial revenues for firms owned by local governments. Local states channel these returns into infrastructure construction outside of each park, proliferating attractions and expanding central towns. While these operations are justified as improving conservation and rural livelihoods, they have mixed impacts on environments and on the lives of residents.

As nature tourism booms in the global South (Balmford et al., 2009; Karanth and Defries, 2011), the ways tourism intersects with environmental conservation draw growing attention (Bushell et al., 2007; Naughton-Treves et al., 2005; West et al., 2006). Much of the resulting scholarship focuses on how tourism development accomplishes neoliberalizing projects, linking conservation to efforts to draw rural territories and residents into commodity circulation (Brockington and Duffy, 2010; Büscher et al., 2012). These actions often weaken or cut off residents' access to protected lands, make residents more dependent on volatile markets, and dilute their roles in decision-making (Dressler and Roth, 2011; West et al., 2006). The state appears as an agent of capital, packaging protected lands for nonlocal entrepreneurs who extract profits from commodified parks to flow in distant circuits (Dressler and Büscher, 2008). China, where state-owned firms dominate nature tourism, raises challenges for neoliberalizing narratives. What happens when the state keeps a robust role in park tourism? How do state 
agencies negotiate environmental and social imperatives alongside those of the market, and with what consequences for residents and for landscapes?

This paper draws on three case studies to characterize the processes driving tourism intensification across China's protected areas and their impacts on people and places. Drawing on interviews and documentary evidence, I characterize state-led "tourism dynamos" that propel tourism intensification and describe their impacts on rural residents and conservation management practices. These transformations hinge on two elements: selective commodification and state mediation. First, the state reserves protected lands from commodity circulation, producing scenic landscapes and giving select tourism operators rights to undertake selective commodification of attraction access. Second, the local state plays a key role in mediating tourism intensification, shaping what happens and who profits. The processes surrounding tourism dynamos show how environmental and productivist logics intertwine to reorganize protected areas within regional tourism networks in China. They also shed light on processes of land use intensification beyond China's urban centers. Finally, they show limitations of the frame of neoliberal conservation, highlighting state projects that manage markets to serve non-market imperatives.

\section{Conservation and Tourism in Protected Areas}

Protected areas ${ }^{1}$ have been sites of wrangling over nature conservation, livelihoods of rural residents, and tourism development at least since the founding of the first national parks in the United States (Adams, 2004; Sellars, 2009). As bounded units of territory demarcated for limited human use in the name of protecting wildlife and ecological processes, for much of their history

${ }^{1}$ In this paper I use the words "protected area" and "park" interchangeably. 
protected areas have been sites of exclusion. Narratives of environmental protection justify extending state territorial control, enclosing resources for state management, and separating residents from lands central to their livelihoods and identities (Neumann, 2004; Peluso, 1992). The state declares places where people live, farm, hunt, gather, worship, and remember, to be conservation territories that must be protected from their former inhabitants. This "fences-andfines" approach, often part of broader state projects for controlling territories and populations, puts rural residents at odds with protected area managers, who act as agents of the state (Adams, 2004; Brockington, 2002; Wilshusen et al., 2002).

Conflicts and injustices resulting from exclusionary conservation aroused vigorous critique, leading to two interwoven turns in conservation practice: the participatory turn and the market turn. Participatory conservation subjects conservation interventions to the requirement that conservation interventions fulfill obligations to people who might be affected. The participatory turn manifests in efforts to recognize that residents' use of protected areas can enhance, or at least not undermine, conservation; to involve residents in management and decision-making; and to provide residents benefits in exchange for taking part in conservation (Brandon et al., 1998; Lele et al., 2010; Pfeffer et al., 2006). The form of participation ranges from providing economic benefits to subjecting outsiders' actions to residents' knowledgeable and autonomous consent.

Participatory interventions are usually wrapped more or less tightly into marketizing interventions. The market turn rests on the proposition that residents and other stakeholders will be better motivated to conserve natural resources if there are economic rewards for doing so. This line of thinking underlies a variety of schemes for economic valuation and commodification of resources, like carbon offsets, commodity certification, and payments for 
ecosystem services (McAfee and Shapiro, 2010; Klooster, 2006). Tourism is prominent among them. Proponents claim that tourism development can resolve problems in conservation management by generating funding for conservation programs, providing employment that draws residents away from resource extraction, and buttressing a park's legitimacy in residents' eyes (Christ et al., 2003; Kirkby et al., 2011). It can also earn hefty sums for outside parties. Alongside other ways of commodifying nature, tourism yields benefits that are often tilted away from local residents (Dressler \& Büscher, 2008; King and Stewart, 1996), raising concerns that market-based conservation practices, while justified with participatory rhetoric, in practice co-opt participatory measures (Lele et al., 2010; McAfee and Shapiro, 2010; McElwee, 2012).

\subsection{Problems in Neoliberal Conservation}

This merger of participatory and market techniques is often called neoliberal conservation (Igoe and Brockington, 2007; McCarthy, 2005). Neoliberal conservation couples a roll-back of previously existing forms of coercive state management to a roll-out of programs bringing in private firms and non-governmental organizations (NGOs) to facilitate community-based conservation efforts, making conservation spaces more available to private capital (Brockington and Duffy, 2010; Büscher et al., 2012; McCarthy, 2005; McCarthy and Prudham, 2004; Robertson, 2004; see also Peck and Tickell, 2002). The state seldom fully retreats. State agencies step in to reregulate access to land and resources to facilitate the projects of NGOs and firms (Dressler and Büscher, 2008; Igoe and Brockington, 2007). These efforts often achieve the same kinds of transformations previously sought through coercive conservation, extending state territorial control, constraining extensive land use within protected areas, and promoting settled commodity agriculture outside them (Ribot et al., 2010; Dressler and Roth, 2011). Where protected area enclosures deprive residents of access to means of production, scholars identify 
patterns of accumulation by dispossession, with the state facilitating dispossession of rural residents that feeds private accumulation (Igoe et al., 2010; Kelly, 2011).

The term neoliberal conservation has become pervasive in scholarship on parks and people. But just as contradiction and ambiguity bedevil broader discussions of neoliberalism (Bakker, 2010; Kingfisher and Maskovsky, 2008), gaps and imprecisions in presentations of neoliberal conservation weaken the concept's usefulness as an explanatory tool (Bakker, 2010; Hathaway, 2014). Central among these is that neoliberal conservation's commodifications depend on landscapes being withheld from commodification. Accumulation by dispossession is generally considered to mean enclosing a commons by creating private property rights, opening land and resources to market exchange. But the move to commodify conservation spaces depends upon a prior move to enclose them from capital, curtailing extraction and reclamation (McCarthy, 2005). Hence conservationists base political claims against corporate interests and residents alike on the nature of protected areas as the "ultimate non-commodity", insulated from market forces (Li, 2008). In some cases this move, which we can call "reservation", is a form of decommodification, withholding from exchange land that had previously been open to sale. Elsewhere, it stems from other sorts of colonial or state-led enclosures. In either case, the commodification of reserved land is substantially limited, as rights to use that land for cultivation, mineral extraction, or other purposes cannot be bought. Only with this precondition can conservation-based commodifications become profitable.

Kelly (2011) asserts that the withholding of protected areas from commodification is illusory because contemporary conservation practices still commodify protected area contents indirectly through the commodification of genetic resources, conveyance of rights to operate tourism, and 
circulation of representations of protected areas (see also Igoe et al., 2010). ${ }^{2}$ This argument fails to consider the extractive, agricultural, and other uses that may occur in the absence of reservation-and which do occur where states weaken statutory protections. The recent opening of oil rights underlying Yasuní National Park in Ecuador (Vaughan, 2014) and calls for the same in U.S. national parks are telling examples. Enforced reservation places substantial limits on commercial uses of land, limits that take effort to get around.

Commodification at a distance shows the ingenuity with which people find ways to profit where conventional means of accumulation are barred. But it also raises new questions. If these forms of commodification happen in places where residents have not lost access to land, and where residents and landscapes are already involved in markets, does accumulation by dispossession adequately describe what is going on? Accumulation by dispossession rests on separating people from means of production. Yet protected area tourism often does not require such a separation. In some instances, residents keep access to agricultural land and have full ownership and decision-making authority over tourism operations (Kirkby et al., 2011; OhlSchacherer et al., 2008). In others, residents are removed or forcibly restricted from using resources reserved for private tourism enterprise (Butt, 2012). Countless variations stand between. The lens of accumulation by dispossession gives little insight into these variations. Insofar as people are being separated from means of production, just what are those means, and what does it mean to expropriate them? It is plausible that if the rights being taken are rights to

\footnotetext{
2 A confusing vagueness surrounds the concept of "commodification". Scholars often present expansive conceptions of commodification such that, if anything related to a given object is sold on the market, that object is considered "commodified". This conception is consistent with commonsense understandings of the word. But it is analytically blunt. Collapsing together the varying ways and extents to which different aspects of an object get commodified makes us less likely to explore their differing consequences. Whether the land used for conservation is available on markets, or is kept off the market while people pay to visit, or buy souvenirs produced there, or to sell materials marked with a park's logo, in each case may have quite different consequences.
} 
operate tourism, to own genetic resources, or to sell media representations, expropriators are likely to treat residents and manage land in different ways. What is needed to "produce" tourism attractions, moreover, differs from what is needed to sell images, carbon credits, or other conservation-related commodities. Each commodification may necessitate different dispossessions. Finally, we need to account for how reservation of land by the state through gazetting mediates these commodifications.

These questions get at the limitations of neoliberal framings for illuminating the variety of ways in which conservation and commodification come together. It is well known that the prospect of profit motivates all sorts of schemes for commercializing conservation. Rather than start from the question of how each one instantiates neoliberalizing processes, it may be more illuminating to start from the specific forms of commodification that happen in particular contexts and to ask what leads these contradictory commodifications to result in differing patterns of dispossession and accumulation.

\subsection{Tourism's Peculiar Commodifications}

Tourism turns on such a contradictory commodification. The core commodity produced and sold in tourism is access to tourism attractions. Tourists pay to enter spaces that provide entertainment and education. More conventional commodities, from souvenirs to transportation to lodging, get sold as well, but their sale depends on access to attractions.

Access may be explicitly sold when tourists buy tickets to enter an attraction. Parties with access privileges may sell activities, acting as gatekeepers or guides for their customers. In other cases ambient scenery can be experienced for free by visitors who pay for food, lodging, transportation, and so on during a visit. 
To produce and sell these experiences, operators need to access or control territory within which to run attractions. As in extractive industries, in tourism "competitive advantage often derives from proprietary access" to land (Boyd et al., 2001) with advantageous prospects for presenting attractions. To package and sell access to an attraction may require infrastructure and vehicles to move tourists around; facilities within which to receive and process them; marketing apparatus to attract visitors; and sundry other things. But access to land on which to stage the experiences tourists pay for is the fundamental element. If land is commodified, a tourism operator may simply buy land to develop. This puts operator in competition with other buyers. Alternatively, an operator might rely on the state to deliver access, whether directly by expropriating other users or indirectly through zoning policies.

In making attractions, tourism operators appeal to tourists' pursuit of authenticity (MacCannell, 1989; Oakes, 1998; West and Carrier, 2004), creating a dialectic of reservation and commodification. The allure of many tourism attractions lies in the appearance of authenticity, of not being polluted by commodification. Tourism operators and tourists take part in fetishizing places as authentic (Butt, 2012; King and Stewart, 1996; Oakes, 1998). ${ }^{3}$ Tourism operators work to remove or disguise traces of human use in landscapes presented as pristine nature, of modernized living among residents presented as traditional, of roads and buildings that disrupt historical settings. To do this effectively, an operator will have to persuade owners of adjacent parcels to accept limits, or else simply buy the land. Again, the tourism operator's task is simplified if limits are placed on what can be commodified and where. Through zoning or special historic or conservation designations, state agencies reserve tourism sites from

\footnotetext{
${ }^{3}$ A similar fetishization may take place where state agencies and NGOs presume residents to undertake traditional, non-commodified production as part of conservation schemes. See Li (2008). 
productive activities that would lessen their allure (Molotch, 1993; Zhang, 2008). Withholding land from commodification by limiting how people can use and exchange it makes it easier for managers to maintain the appearance of authenticity.

In a weakly regulated market, keeping this veneer of authenticity is costly. A single tourism operator may have to buy up land or bargain with neighbors. Operators in a locality may organize to bargain with other landowners or lobby for zoning rules that protect their interests. These costs may fall substantially if the state designates land with potential for tourism development for particular uses and conveys exclusive access to a tourism operator, while also reserving surrounding lands, providing assurance against adjacent development that would devalue an attraction. These two actions lower the costs and increase the potential gains for a tourism operator. Establishing a protected area can achieve both. State-mediated reservation of the site and its surroundings provides for selective commodification, enabling operators to sell access to an attraction while limiting the ways the land holding the attraction can be exchanged and developed.

These state-mediated reservations and selective commodifications facilitate the processes through which tourism operators intensify tourism-based land use. A tourism operator invests in attraction infrastructure and services in order to increase the amount people pay to visit, the number visiting, or both. As with land reservation, having the state provide infrastructure cuts private costs. Commonly recognized dynamics of land use intensification play out: rentiers intensify land use to extract rents and push the state to facilitate access and support development (Logan and Molotch, 1987). Over time, attractions are transformed in shape and meaning. Attraction amenities fill spaces that once served other purposes for local residents, who are constrained to use these spaces for tourism activities (Zhang, 2008). With the state 
assuming the costs of providing exclusive access and regulating surrounding land use, the tourism operator is freed up to intensify rent extraction through attraction development.

\subsection{Protected Area Tourism and the State in China}

The foregoing discussion might well set up a study of roll-out neoliberalism as the state assists private accumulation in tourism. But the cases that follow show the state spearheading tourismbased accumulation and managing it to channel capital for state projects. China's political economy poses difficulties for neoliberal framings. Scholars taking political-economic perspectives, exemplified by Harvey (2005), picture the retreat of the state from firm ownership and service provision, the incursion of transnational investment, and the ensuing export-led growth, expanding inequality, and environmental degradation as a neoliberal transformation (see also Wu, 2008). Scholars taking a Foucauldian governmentality perspective highlight a shift from coercive mobilization to discourses and techniques aiming to cultivating subjects who are knowledgeable, self-managing consumers (Anagnost, 2004; Greenhalgh and Winckler, 2005; Yan, 2003). Inconsistencies in the tactics, justifications, and outcomes of cultivating personal "quality" (suzhi) show the limits of seeing it through a neoliberal lens (Kipnis, 2007; Nonini, 2008). Meanwhile, the persistence of state-directed firms and sectors, run in ways that serve interests in tension with those of global capital-promoting national accumulation and bolstering state capacity—challenge neoliberal framings from political economy. Some have met these incongruities by reconceptualizing neoliberalism as a flexible, context-dependent tendency (Brenner et al., 2010; Ong, 2007), or introducing a Chinese variant of “state neoliberalism" (So and Chu, 2012). The conceptual acrobatics needed to fit these phenomena into a neoliberal framing suggest that a different approach might prove more revealing. Therefore, I take the challenges and opportunities surrounding conservation and development 
in remote areas as a starting point for understanding the patterns China's political economy generates.

China has been at the forefront of the rush to develop tourism in protected areas. Since 2000, under programs of "ecological construction," the central government has intensified investments in protected areas (Li et al., 2013; Yeh, 2009). Their management shows concerns similar to those raised elsewhere. Protected areas impose restrictions on millions of rural residents, while exclusion from decision-making can constrain already marginalized rural populations (Xu and Melick, 2007; Yeh, 2013). Yet a number of China's protected areas have brought residents involvement in conservation management and economic benefits (Albers and Grinspoon, 2004; Herrold-Menzies, 2006; Weckerle et al., 2011). While central and provincial agencies drive protected area establishment, local (county or municipality) governments ${ }^{4}$ are charged with day-to-day management and expenditures. Local governments are often poorly motivated to devote resources to conservation management, which brings neither revenue nor promotion prospects. Many parks remain short of staff and skills and implement rigid rules with little basis in conservation science (Harris, 2008; Quan et al., 2011; Xie et al., 2004; Xu et al., 2012; Zhou and Grumbine, 2011).

Government promotion has made many protected areas into lucrative attractions. National and local governments have vigorously supported tourism within rural development and poverty alleviation efforts (Donaldson, 2007; Zeng and Ryan, 2012). From the 1980s, local governments initially pursued tourism development as a way of generating foreign exchange. But as increasingly affluent urban residents seeking refuge from crowded, noisy, and smoggy cities

\footnotetext{
4 The municipality is the administrative level below the province, with the county below the municipality. In ethnic minority areas, the municipal-level unit may be called a prefecture. Below, the term "local state" refers to these levels.
} 
have flooded into nature attractions, domestic tourism has become predominant (Chio, 2014).

Growth in visitation and revenues in nature attractions has outpaced other tourism sectors, and in 2010, tourists made over 390 million visits to China's forest parks and nature reserves (Zhuang and Huang, 2011). Domestic travelers account for over $90 \%$ of the total (ibid.).

Local governments in remote, rugged regions where avenues for industrial and agricultural growth are scarce often find tourism a ready means to meet pressure to increase revenues. So they have turned to scaling up tourism at scenic attractions. This strategy generates substantial economic growth; in the last two decades, many centers of scenic tourism have experienced sustained double-digit rates of tourism revenue increase, exceeding growth rates in most other sectors and regions. However, tourism's contributions to conservation and resident livelihoods are ambiguous (Han and Zhuge, 2001; Xu and Melick, 2007; Wang et al., 2011).

State promotion of protected area tourism shows how institutional pressures bring a complicated synthesis of environmental logic of conservation with productivist logic of tourism intensification. The state has reserved land in China's protected areas in accord with an environmental logic, setting land aside to provide environmental values. In nature reserves, tourism development is allowed in specific zones "under the condition that it does not affect the environment and natural resources" (State Council, 1994, Article 22). Regulations concerning other protected area categories stipulate similar constraints. Although commercial spaces can be contracted to private operators, land within these areas is not permitted to leave government control.

Local governments are thus obligated to hold park lands off of the market. This raises challenges for local officials who face pressure to maximize revenues and growth, which they usually address by commodifying land. Land-based development strategies have been amply 
explored in urban and periurban contexts, but much less in rural areas. While capitalist real estate activity is central to the transformation of China's cities, urban land is not fully commodified. Local governments use their regulatory powers to displace occupants of strategic parcels at low cost, then sell the parcels to developers to generate revenue (Ho and Lin, 2003; Tao et al., 2010; Xu et al., 2009). They often employ financing platforms, state-owned enterprises that mobilize loans and securities using public assets as collateral, to channel urban development (Tsui, 2011). In periurban areas, governments use commensuration and transfer mechanisms to convert collective housing land into commodified farmland and commercial real estate (Chen, this issue; Zhang and $\mathrm{Wu}$, this issue). Rather than buffering against accumulative use, the partial commodification of land facilitates these transformations by concentrating authority in the hands of revenue-hungry governments.

Further from cities, the real estate markets that propel urban land commodification are scarce. Yet, counterintuitively, China's protected areas pose even stronger targets for intensification than urban land, precisely because they are sheltered from market exchange. Without the industrial, commercial, and real estate avenues to land-use intensification available in cities, rural governments scramble to attract investment and generate revenue (Smith, 2010). For local governments fortunate enough to have them, scenic amenities enclosed in protected areas provide a ready solution. Required to keep protected areas off the market and enabled to oversee tourism development, local governments use state-owned financing platforms to obtain capital, invest in tourism upgrades, and extract rents through tourism operations, all without land sale. Rather than being manipulated by private capital to facilitate private development projects at a remove by issuing supportive policies, local governments directly run and profit from tourism operations. 


\section{Methods}

To examine patterns of tourism and park management, I undertook multi-sited ethnography in several protected areas in southwestern China. I began with an exhaustive review of scholarly literature and government documents concerning protected areas in southwest China. On that basis, I chose ten protected areas for examination, including four with large-scale tourism operations and three with tourism operations of intermediate scale. ${ }^{5}$ During field work in 2010 and the summer of 2011, I visited each park and conducted 37 semi-structured interviews with officials, researchers, and NGO personnel involved with each protected area. The interview script covered the history and nature of tourism operations; conservation targets and management practices; community affairs; sources and disposition of funds; and interactions with government agencies and non-government organizations. I also consulted primary and secondary documents pertaining to each park. Data from interviews and other observations were coded and examined iteratively for themes following Charmaz (2006). The following cases typify processes evident across protected areas that have been transformed to facilitate highvolume tourism.

\footnotetext{
${ }^{5}$ The full sample includes Caohai National Nature Reserve and Biosphere Reserve in Guizhou Province; Dongting Lake National Nature Reserve and Zhangjiajie National Forest Park-Wulingyuan World Heritage Site in Hunan; Jiuzhaigou National Nature Reserve, Wolong National Nature Reserve, and Wanglang National Nature Reserve in Sichuan; and Baima Snow Mountain National Nature Reserve, Meili Snow Mountain National Park, Pudacuo National Park, and Xishuangbanna National Nature Reserve and Biosphere Reserve in Yunnan. Extended participant observations were undertaken during 2010 in communities within Meili Snow Mountain and Pudacuo.
} 


\section{Three Tourism Dynamos}

\subsection{Zhangjiajie-Wulingyuan}

One of the first nature attractions to adopt an intensified tourism model was ZhangjiajieWulingyuan in Hunan Province. Through the 1970s, Zhangjiajie State Forest in Dayong Municipality was operated for timber production. In 1979, local authorities brought the nationally renowned painter Wu Guanzhong to the forest farm. Captivated by Zhangjiajie's towering karst formations, Wu publicized Zhangjiajie in a widely reprinted essay $(\mathrm{Wu}, 1980)$ and memorialized it in paintings. In the following decade, the region was administratively reorganized around the attraction. The government of Dayong Municipality mobilized to develop tourism facilities, and the State Forestry Administration made Zhangjiajie a pilot site for forest tourism development (Zhong et al., 2008). In 1982, Zhangjiajie was named China's first national forest park. In ensuing years, the region was administratively reorganized around tourism. A new Wulingyuan administrative district, housing Zhangjiajie Forest Park and two abutting nature reserves within Wulingyuan Scenic Area, was carved out of three adjacent counties in 1988. Four years later, the municipality was officially renamed Zhangjiajie Municipality.

The explosion of tourism that these developments brought transformed landscapes, livelihoods, and governance. In 1989, annual visitation reached 381,500. Tourism operations centered on small businesses, many run by residents of communities within and around the attraction. Local residents gave visitors rides to scenic spots on sedan chairs, and they had opened 60 household hostels by 1990, alongside 32 hotels and 190 shops (Zhang and $\mathrm{Xu}, 2007)$. While residents continued to farm, tourism became their main source of income. Local, provincial, and national governments invested in road, rail, and airport infrastructure to bring in tourists. The county 
government aggressively marketed the attraction, holding exhibitions across the country and abroad.

Continuing tourism growth and the construction of mass tourism infrastructure marked the 1990s. In 1992, authorities of the newly formed Zhangjiajie Municipality applied for designation as a World Heritage Site by the United Nations Educational, Scientific, and Cultural Organization (UNESCO). In 1992, UNESCO declared the Wulingyuan Scenic Area a World Heritage Site. In conjunction with this effort, the agency overseeing the site invested in a system of roads and buses to shuttle visitors through the park. Zhangjiajie Municipality founded the Zhangjiajie Tourism Group Company, Limited (hereafter Zhangjiajie Tourism Group) to manage major functions including ticket sales and the bus system. Through the 1990s, short of capital, Zhangjiajie Municipality and Wulingyuan District governments sought private investment to build attraction infrastructure. Companies from Hong Kong and Taiwan invested in cable-car lines in return for rights to operate them for several decades.

In 1998, inspectors from UNESCO issued raised alarm about tourism expansion in Wulingyuan, citing impacts on scenery and water quality in the World Heritage Site. This warning spurred a further wave of tourism consolidation and infrastructure construction. The government of Zhangjiajie Municipality issued new regulations for the park, extending restrictions on resident tourism activities (Wulingyuan Scenic Resort Administrative Department, 2002). Most accommodations inside the park were closed. By the end of 2001, fifty-nine tourism structures had been demolished, and 377 households had been moved outside the attraction. Meanwhile, a joint venture between a firm based in Beijing and two foreign firms built an elevator to take batches of tourists up a promontory. By 2002, 59\% of Zhangjiajie Municipality's tax revenues 
came from tourism, up from about 20\% in early 1990s, and in 2005, tourism-related industry accounted for $54.4 \%$ of economic product in Zhangjiajie Municipality (Zhong et al., 2008).

Over the past decade, the government of Zhangjiajie Municipality has pushed to expand its control of revenue from tourism attractions. The government of Zhangjiajie Municipality maintains a controlling interest in the Zhangjiajie Tourism Group through a state-owned holding company. Subsidiaries of the Zhangjiajie Tourism Group operate ticket sales for the main attraction and several smaller ones, bus and shuttle services, travel agencies, and a hotel. In 2012, the firm made a net profit of RMB 136.7 million on RMB 682.4 million in revenues; attraction operations earned the bulk of profits (Zhangjiajie Tourism Group, 2014). As access to capital through the Zhangjiajie Tourism Group has grown, authorities have invested in attraction development through this company rather than seek outside investment. A Zhangjiajie Tourism Group subsidiary built and operates the newest addition to the park's facilities, a cable car. Of its ticket proceeds, $23.7 \%$ go directly to the municipality government (Huang and $\mathrm{Gu}, 2014$ ).

Tourism at Zhangjiajie-Wulingyuan has brought major economic resources to the local state in what had been an impoverished backwater. While the Zhangiiajie Tourism Group has sought greater state control over key attraction assets, Zhangjiajie-Wulingyuan supports an exuberant private tourism economy with major hotels, travel agencies, and performance venues concentrated among a few dominant firms alongside hundreds of smaller hotels and restaurants. Tourism expansion has also brought substantial income to residents in the park's immediate vicinity, even while giving them increasingly marginal roles. Sedan chair rides have disappeared. While there are still a handful of guesthouses within Zhangjiajie-Wulingyuan, most resident-supplied accommodations are outside the park. Households that had previously 
run businesses within Wulingyuan received space to operate outside its gate. The park has compensated residents for requisitioned land and provided employment for over 800 residents, as well as cash incentives for residents to migrate to work elsewhere (Zhangiiajie Municipality People's Government, 2011). Impacts on the conservation of geological features, vegetation, and wildlife within the World Heritage Site are mixed. Tourism infrastructure has dramatically altered the landscape; the elevator's impact has been particularly controversial. While the Zhangjiajie Environmental Protection Bureau measures air and water quality, management agencies do not regularly monitor plant and animal communities, much less actively implement conservation management measures (Wang et al., 2009, 2010). Nonetheless, ZhangjiajieWulingyuan has become a model for local governments seeking to convert scenic resources into major tourism attractions.

\subsection{Jiuzhaigou}

Jiuzhaigou, in Aba Qiang and Tibetan Autonomous Prefecture in northwestern Sichuan Province, had also been a logging district before it was designated a nature reserve in 1978 . The park's opalescent pools and mountain vistas soon began to attract visitors. Guesthouses proliferated in villages, while the administration office of Jiuzhaigou Nature Reserve collected ticket fees. In 1992, along with Zhangjiajie-Wulingyuan, Jiuzhaigou was designated a World Heritage Site, and the administration office set up a company to organize visitor services, working to facilitate residents' guesthouse business. Rapidly expanding tourism raised concerns like those seen at the same time in Zhangjiajie. Tour buses crowded narrow roads, and the management of residents' guesthouses was difficult to coordinate. In 1999, the government of Aba Prefecture, in which Jiuzhaigou is situated, announced a plan to adopt a new model of "touring in the valley, staying outside the valley," and reconstruction began. In the next three 
years, roads and buildings were constructed, a set of low-emission buses were purchased, guesthouses were closed, and farming and livestock grazing were curtailed.

Over the following decade, local governments attempted to privatize tourism operations at Jiuzhaigou, then changed tack and reconsolidated public control. Through the 1990s, the Jiuzhaigou Nature Reserve Administration Bureau had overseen conservation and community affairs while also operating ticket sales and owning hotels, souvenir concessions, and a mineral water firm. In 1998, as county and prefecture governments prepared to scale up the attraction, these holdings were consolidated into the Jiuzhaigou Tourism Development Group, which raised funds to build mass tourism infrastructure. Jiuzhaigou authorities attempted to organize a public offering of stock in 2000, but central ministries vetoed this privatization of public resources. Subsequently, Aba prefecture intensified capital mobilization through the holding company. In 2006, the prefecture government folded assets at four attractions including Jiuzhaigou into a state-owned holding company, the Aba Prefecture Greater Jiuzhaigou Tourism Group. This consolidation has given the prefecture hold of key levers in an industry that is estimated to account for $60 \%$ of economic product in Jiuzhaigou County (Hou, 2013). The budget for Jiuzhaigou is part of the Aba Prefecture budget, its funds overseen by the prefecture finance bureau. For the main tourism season, 30\% of ticket revenues were directed to the prefecture government, $8 \%$ the county government, 59\% to the Administration Bureau to cover operating costs, and 3\% to resident households (Aba Prefecture People's Government, 2006). Following the 2008 earthquake in nearby Wenchuan, visitation plummeted, though by 2011 it rebounded to over 2.8 million visits (Zhuang et al., 2012).

The decade also saw a dramatic change in the role of residents. New rules forbade farming, livestock grazing, and the use of forests for firewood, with the intention of producing a pristine 
environment absent signs of human use (Urgenson et al., 2014). In return, residents received a portion of ticket proceeds and the option to buy shares in a company running restaurant and shopping concessions, owned $77 \%$ by residents and $23 \%$ by the Administration Bureau. Hamlets inside the park were concentrated into three settlements that were administratively redefined into urban neighborhoods, and over 1,000 residents were granted urban household registration. Initially, residents resisted the prohibition of farming and accommodations within the park. Management responded by committing to provide employment for residents in visitor services, conservation patrolling, and fire suppression. By 2004, virtually all working-age residents from within Jiuzhaigou were employed by the attraction. Residents of communities within the park have far higher incomes than those in surrounding areas, with an income of RMB 41,000 per capita in 2007, above the national average for urban areas. Yet their proportion of the attraction's income fell from $42 \%$ to $6 \%$ between the 1990 s and 2007 (Tian, 2010).

Jiuzhaigou authorities have aggressively implemented forest conservation policies and begun to monitor conservation targets, but environmental protection is primarily oriented toward visitor experiences. In 1998, the park set up several environmental monitoring stations, and according to policy, monitoring should drive decision-making. Its science office conducts water quality and wildlife monitoring, though researchers active there report that these practices are not done systematically enough to provide reliable data. Funding for these functions from tourism revenue is dwarfed by allocations to tourism operations and maintenance of tourism façades. Presenting environmental protection achievements, Jiuzhaigou's administration emphasizes reducing automobile and hiker traffic, managing solid waste, and ending residents' withdrawals of natural resources (Li et al., 2006; Tian, 2010). By halting grazing that maintained diverse meadows, resource use restrictions have diminished biodiversity in the park's alpine 
landscapes (Urgenson et al., 2014). In a recent assessment, the China National Committee for the Man and Biosphere Programme raised concern that "the administration of the Jiuzhaigou Administrative Bureau revolves entirely around tourism expansion, and activities like infrastructure construction and outreach are mainly oriented toward increasing visitor numbers" (Ma, 2009: 3).

\subsection{Pudacuo}

After Zhongdian County in the northwest of Yunnan Province opened to tourism in 1994, tourists appeared in growing numbers at Bita Lake, an alpine water body surrounded by wetlands and rocky peaks. Residents of nearby villages began providing horse rides and accommodations. The management office of Bita Lake Provincial Nature Reserve set up a ticket office and helped residents collectively organize horse ride services. The forestry bureau of Zhongdian County used some of its own funds and a bank loan to undertake initial development. In 1997, staff from the Bita Lake Nature Reserve worked with residents to organize a rotating horse ride service cooperative, while the county government set up a company to operate ticket sales. That company was briefly privatized in a joint venture with the Huaneng Lancang River Power Company. In 2003, the county government withdrew the company's operating rights. The following year, the county government established a new state-owned firm, which commenced construction of high-volume tourism infrastructure (Tian and Yang, 2009). In 2006, this firm was incorporated into the Diqing Prefecture Tourism Development Investment Company (TDIC). ${ }^{6}$ The TDIC undertook a RMB 210 million investment in roads, low-emission tour buses, visitor facilities, and waste management systems.

${ }^{6}$ In 2012, the TDIC was reincorporated as Diqing Tourism Development Group, Limited, remaining under the control of the prefecture government. 
In 2006, the attraction reopened as Pudacuo National Park, a central stop on tour routes through a county that in 2002 had been renamed Shangri-la. In 2007, its first full year of operation, the park sold over 566,000 tickets, more than doubling the 253,100 visitors to Bita Lake in 2002 (Ye et al., 2008). The Pudacuo National Park Tourism Services Company, a TDIC subsidiary, operates the attraction. The Pudacuo National Park Administration Bureau is responsible for conservation and community affairs. When disputes arise between the company and the bureau, TDIC managers receive preference, resulting, for example, in delayed compensation payments to residents and limited funding for conservation. Officially, operating revenues are distributed $60 \%$ to the firm, $20 \%$ to prefecture government finances, and $20 \%$ to county government finances (Tian and Yang, 2011). Of the RMB 117.98 million in profits Pudacuo realized between 2006 and 2009, RMB 75 million were transferred to the prefecture, in addition to RMB 17.7 million in taxes (Diqing Prefecture Tourism Development Investment Company, 2010). Based on these figures, $78.6 \%$ of the company's profits were transferred to the local government, equivalent to $7.9 \%$ of the prefecture government's budgeted revenues for those four years.

While before the upgrade county, township, and nature reserve officials had facilitated community-based tourism activities, with the establishment of Pudacuo National Park, their stance toward residents became one of regulating residents' activities and managing complaints. Residents have gone from providing horse-rides and refreshments directly to tourists to serving as sanitation workers in the park. Each year the park gives each household a compensation payment based on the number of household members. In 2009, these payments and income from sanitation employment amounted to less than 5\% of the park's revenues (Zinda, 2012). Residents continue farming and gathering forest products in collective lands, and several households pasture yaks and cattle as tour buses shuttle by. A Community Affairs Committee 
comprising representatives of villages, the park administration, the tourism company, and township and county governments provides an arena for consultation and negotiation. Residents' leverage is limited, though they have succeeded in using this committee to secure increased compensation. Park personnel treat residents as petty claimants. A staff member recounts:

\begin{abstract}
When activities like horse-pulling were halted, people didn't like it, so we had to do a lot of community work. I was the first to do community work, every day haggling with the residents. They signed a threeyear contract, every household got three thousand yuan in compensation. Then they quieted down. After three years, they signed a new contract. The villagers started causing trouble (naoshi) again. They wanted two thousand for every person on top of the three thousand per household.
\end{abstract}

Local authorities prioritize tourism revenues over conservation management. Officials at Pudacuo, while not revealing precise figures, report that a small proportion of the park's tourism earnings are expended on conservation management. Bita Lake Provincial Nature Reserve, which covers one-third of the park's area, receives funding from national and provincial agencies for projects targeting specific species and wetland areas, as well as through facilitating research by visiting scientists. In 2010 the Yunnan Province Forestry Department supported a baseline study of vegetation and wildlife, though this program did not establish an ongoing monitoring program. Nonetheless, the Pudacuo National Park Administrative Bureau, responsible for conservation and community affairs, lacks funding and staff sufficient for regular patrolling and monitoring activities. In contrast, park authorities make substantial investments aimed at enhancing visitor experiences. 


\section{Discussion}

\subsection{Tourism Dynamos}

Zhangjiajie-Wulingyuan, Jiuzhaigou, and Pudacuo typify a pattern of tourism intensification that has become increasingly widespread. In each case, local governments have reconstructed attractions around high-volume tourism infrastructure and set up state-affiliated firms to operate attractions and coordinate tourism enterprise. These operations reconfigure tourism attractions to intensify revenue extraction, subordinating the practices through which residents had previously used these landscapes for subsistence and for profit. They show a pattern of increasing state ownership, partial alienation of residents from places they have called home, and a focus of conservation efforts on maintaining scenic façades for visitors. This pattern emerged as pressures on county and prefecture governments to generate revenues met with the arrival of new vehicles for mobilizing capital to upgrade tourism attractions.

I call this pattern the tourism dynamo. A dynamo is a simple electric generator in which a coiled wire spun between the poles of a magnet yields electric current that can be used to perform work. The analogy to a dynamo evokes how local states harness the circulation of tourists through tourism attractions to power projects beyond park borders. Tourism dynamos built around protected areas circulate tourists about the poles of an attraction, generating revenues that local states invest in infrastructure and further attractions.

The device that makes these dynamos run is the protected area attraction, where an environmental logic of conservation and a productivist logic of intensification combine to yield a charge of revenue through selective commodification mediated by the state. Protected areas epitomize an environmental logic, with the state reserving land from market exchange and restricting its economic use in order to provide environmental goods and services. These 
constraints present a problem for local states that must implement productivist strategies to meet requirements to grow local economies and raise revenue. In the tourism dynamo, China's institutional context yields a rewarding solution. In the face of rules forbidding some profitable activities, local states intensify tourism in designated zones while reserving other areas for strict conservation, accomplishing functional intensification. The reservation of land in the name of environmental values, a process mediated by provincial and central agencies, enables county and prefecture governments to monopolize access. In turn, local agencies turn a portion of each park into a staging ground for commodified tourism products. Reservation and state enterprise resolve the tension between environmental and productivist logics in the interests of local states, not external capital.

Central state directives and personnel management policies compound competitive pressures that have helped these models to diffuse. With revenue growth a core criterion of cadre evaluations that determine their career prospects, local officials have long been primed to seek ways to develop sectors with large short-term returns and to channel those returns into government finance (Whiting, 2004; Smith, 2013). Central and provincial governments promote tourism consolidation as a way to accomplish this goal in deep rural areas. They often prescribe the general contours of tourism development in documents like Yunnan Province's guidelines for a "second phase of innovation" in tourism, which mandates larger-scale, higher-quality attractions; enhanced place branding, and the development of regional tourism routes (Yunnan Provincial Committee of the CPC and Provincial Government of Yunnan, [2004] 2006). Officials look to these directives and to existing successful "models" to inform their tourism development strategies (Zinda, 2014). These factors come together in a hypercharged form of place competition that replicates intensified attractions across locales endowed with tourism 
amenities (see Nyíri, 2006). Competing to attract tourists and their yuan, in locale after locale, local governments set out to foster distinctive local brands—signature presentations of authenticity—by inserting locally specific elements into a template of scenic attractions run by state-affiliated firms, marketed with images of local flavor, linked to commercial centers via standardized tour routes.

In responding to these pressures, local governments have been enabled increasingly to steer tourism intensification over time by growing capacity to access and mobilize capital. In the late 1990s, during a nationwide campaign to privatize state-owned concerns, local governments sought private investments to scale up attractions. The privatizing trend reversed in the early 2000s as state-owned investment platforms began to proliferate, enabling local governments to mobilize capital without depending on outside investors. Subsequently, local governments have tended to set up state-owned companies to operate attractions, allocating revenues to operational expenses and infrastructure investments outside protected areas.

Changing their stance toward residents from one of community support to one of community management, state-led tourism dynamos have closed down community-based tourism operations and reincorporated residents as employees. Into the 1990s, local governments promoted collective operations that concentrated the benefits of tourism in the hands of rural residents and often involved a high degree of self-management by rural communities. Subsequently, high-volume operations have displaced resident-run operations. These moves have been justified by rationales that resident-operated tourism activities are inefficient and that residents are unruly and difficult to regulate. Indeed, resident-run tourism services are not easily compatible with high-volume visitation. As employees or concessionaires, residents are easier to manage. Following the reorganization of tourism attractions, residents' incomes grow 
absolutely, but their options for engaging in tourism service provision narrow, their latitude in using land around their homes diminishes, and their proportions of revenues decline.

Removing residents is seldom necessary to make a tourism dynamo run. What the tourism dynamo needs is control over tourism activities unfettered access to the space where they happen. This can happen in different ways, depending in part on where residents are situated relative to the attraction. In Zhangjiajie, most (but not all) residents had their homes removed from the park, and many operate hotels, restaurants, or shops associated with Zhangjiajie. Residents of Jiuzhaigou kept their homes but lost the right to run guesthouses, to use those homes as tourism space. They also lost access to farmland and pasture to authorities' vision of woodland scenery. In Pudacuo, residents have kept their homes, fields, and flocks, but have lost the right to run their own tourism operations on state land in the park. Each example shows different forms of displacement and reincorporation as the local state has sought to control key means of tourism production (Table 1). Each has brought on complicated, varied, and changing responses—discontent, negotiation, acceptance, resentment, opportunism. Some residents miss the autonomy of running tourism services on their own. Others are glad the drudgery of hauling tourists is bygone. But seeing others profit from lands they claim a right to, residents frequently demand greater shares. In line with pressures to maintain social stability, local states are increasingly trying to mollify residents with mediating bodies like the one set up in Pudacuo. 
Table 1. Varying Access Loss and Reincorporation in Case Studies

\begin{tabular}{|l|l|l|}
\hline Site & Access lost & Reincorporated as \\
\hline Zhangjiajie & Farmland, homes & Petty capitalist renters \\
\hline Jiuzhaigou & $\begin{array}{l}\text { Farmland, pasture, homes } \\
\text { as tourism space }\end{array}$ & Employees, shareholders \\
\hline Pudacuo & $\begin{array}{l}\text { Organizational autonomy, } \\
\text { state land as tourism space }\end{array}$ & $\begin{array}{l}\text { Employees, compensation } \\
\text { recipients }\end{array}$ \\
\hline
\end{tabular}

These efforts at reincorporation and the mediating arenas that local states establish to consult with residents show a third logic in action: a political logic of stability maintenance. As residents object to losing valued assets and receiving small shares of ballooning profits, local authorities attempt to mollify them by providing compensation and other conditions negotiated in these mediating arenas. Often this takes a form that Lee and Zhang (2013) have called "protest bargaining," which diverts conflict into negotiating terms of compensation. Denied access to means of tourism production, and often other productive assets as well, households are offered compensation, employment, or petty business opportunities that make them reliant on the tourism dynamo.

Meanwhile, local states' preoccupation with extracting revenue constrains conservation investments. Pressures to extract revenue by replicating mass tourism models far exceed inducements to promote conservation. As a result, authorities focus environmental protection efforts on features that are central to visitor experience: water quality, waste removal, visible scenery. This preservation of scenic façades (Sellars, 2009) often fails to satisfy conservation advocates who prefer more active conservation management based on monitoring of dynamic populations and habitats. While official accounts of these transformations proclaim a turn from a sole focus on expanding tourism to emphasis on nature protection, the connection between intensified tourism operations and conservation management is weak. Park agencies charged 
with biodiversity conservation depend on support from provincial and national conservation agencies for training and operational funding. Such support is tilted toward protected areas hosting charismatic megafauna (Author, 2013). Provincial efforts like giant panda conservation programs in Sichuan and initiatives to build protected area management capacity in Yunnan, as well as recent national-level proposals following the inclusion of experimenting with a centralized national park system in the list of tasks issued following the third plenum of the $18^{\text {th }}$ congress of the Chinese Communist Party (Central Committee of the Communist Party of China, 2013; Zhang, 2014), may harbinger an expansion of such efforts.

Tourism dynamos propel processes of regional tourism development that extend beyond park boundaries. Local governments construct tourism circuits that carry tourists between sets of attractions and commercial and hospitality districts in urban centers. High-volume scenic attractions draw tourists to a region, supporting businesses in central towns and generating clusters of hotels, restaurants, and shops along transportation corridors. Attraction development also fosters clusters of business in gateway areas, like hotel and retail clusters around the entrances to Jiuzhaigou and Zhangjiajie. Private entrepreneurs bargain with local governments, and firms with current or former officials on their boards or payrolls—often privatized successors to state-owned firms-have major advantages. In Diqing, for example, a major hotel and the only local travel agency authorized to serve foreign tourists are privatized successors to state-owned enterprises, and their managers are former government personnel. While the interests of the state and private capital are aligned, the state sets the agenda and terms of the relationship, and private firms operate within the confines of state planning (guihua) decisions. 
Numerous case studies support the claim that the tourism dynamo model is becoming increasingly prevalent, though community-centered operations and attractions run by private firms persist in some locales (Chio, 2014; Donaldson, 2007; Oakes, 2006). At Shennongjia National Nature Reserve in Hubei, growing tourism revenue has facilitated investments in tourism infrastructure over ten times greater than conservation investments, which have mainly gone to building facilities and removing residents (Xiang et al., 2012). In Yangshuo, Guangxi province, the county government assumed control of boat tours among the area's rock formations. Residents whose farmland was appropriated for tourism often work illegally as guides for lack of satisfactory legitimate job prospects (Qin et al., 2011). At Huanglong, a site near Jiuzhaigou renowned for both scenic vistas and temples, tourism intensification led by the county government has remade religious sites and limited residents' role in the interpretation of religious and natural heritage, inciting contestation (Kang, 2009). Urban historical sites have undergone analogous transformations as local governments reconstruct them to accommodate high-volume tourism operations, fundamentally altering their contents and pouring revenues into municipal coffers (Feng, 2008; Su, 2010; Wang and Bramwell, 2012; Zhang, 2008). In each case, an organizational and physical reconstruction transforms scenic places into tourism dynamos dominated by the local state.

\subsection{Selective Commodification and Developmental Conservation}

These tourism dynamos raise questions for scholarship on neoliberal conservation. Clearly capitalist mechanisms are at work as tourism dynamos use market mechanisms to make profits. But the forceful action of the state not to make assets available for private capital but to generate revenue for state projects strains even roll-out and variegated conceptions of neoliberalization (Brenner et al., 2010; Peck and Tickell, 2002). Likewise, their use of these profits to meet 
bureaucratic mandates and to invest in regional infrastructure and attraction networks contrasts with the unmoored accumulation strategies that characterize neoliberalization. Rather than leak into the coffers of distant tourism investors, profits circulate within the region through state investments. Finally, the partial dispossessions residents face do not accord well with narratives of accumulation by dispossession. These cases bring to light selective commodification and state mediation, elements that are present in cases of protected area tourism development worldwide, but which often recede from view.

Tourists seek places that appear not to be sullied by commodification, and operators of protected area attractions seek to fulfill this desire. Because protected area rules restrict extractive use within parks and keep the lands within off the market, it is easier for tourism operators to provide the semblance of pristine landscapes than it would be if they had to do so through private markets. Reservation from commodification underpins the intensification of value extraction through tourism in China and elsewhere. It also makes protected area commodifications difficult to account for in the conceptual framework of neoliberalization, calling up arguments that dispossession and commodification happen at a distance (e.g. Kelly, 2011). Looking at how, by impeding other commodifications, protected area reservation serves a particular segment of capital, provides a more direct explanation. States establish protected areas in response to a number of political pressures. This presents real obstacles to the commodification of these landscapes. But these obstacles for some would-be users are opportunities for others where the state expedites selective commodification.

So the role of the state in mediating protected area commodification is key. Doubtless, the tourism dynamos presented here result from particular ways that the state mediates selective commodification for tourism in China. But China's tourism dynamos can be seen as a pole of a 
spectrum of state-capital relationships around protected areas. States exert varying autonomy relative to capital, in some cases apparently relinquishing protected areas to private actors (Dressler and Büscher, 2008) and in others offering concessions to outside bidders with stringent constraints (Machlis and Field, 2000). How states mediate selective commodification shapes how attractions are packaged and sold and where the returns go. Instead of broadly observing that each state engagements with tourism in protected areas instantiate variegated neoliberalizations, we may learn more by examining what particular circumstances lead states to make parks available to capital in different ways, and with what differing consequences for landscapes and human inhabitants.

Because tourism does not require wholesale commodification of parks and their features, and because states that mediate this commodification face pressure not just to accommodate capital but also to appease their subjects, the dispossessions that accompany protected area commodification are partial. Where residents fall in relation to planned tourism operations-in the spatial locations of their homes and activities, as well as in the ways their activities relate to specific tourism projects—shapes how tourism developers engage residents. Residents may lose access to land where its uses disrupt projects to present "natural" vistas. On the other hand, they may keep access, often in newly constrained ways, where their "traditional" livelihoods become part of the attraction. Private tourism operators as well as states may use many tactics to quell resistance or to cultivate acceptance of tourism operations. The literature on parks and people could do better to account for situations in which residents are reincorporated, resistance is muted, consent is cultivated. We need to pay more attention to the sophisticated ways states and firms engage people and environments. 
In line with other calls to move toward more nuanced pictures of market-engaged conservation (Brockington and Duffy, 2010, Dressler and Roth, 2011), these observations call us to look to other logics alongside the neoliberal. Neoliberal framings often appropriately draw attention to marketizing processes, but they may also become blinders that hinder us from understanding processes rooted in other logics. The processes that produce tourism dynamos in China share with neoliberal conservation a profit orientation and the use of market forces, but with a state role and stance toward residents that concepts of neoliberalism and neoliberalization can only accommodate with strenuous conceptual contortions. This form of state regulation of the market is hardly emancipatory. One might label it, with a nod to scholarship on fastindustrializing economies (Evans, 1995; Woo-Cumings, ed., 1999), developmental conservation. This label evokes the ambiguities of developmental states, which have generally been authoritarian and more closely aligned with industrial elites than with ordinary citizens (Kohli, 1994). Thinking in terms of developmental conservation directs our focus to how states manage, constrain, and exploit accumulation processes in the face of demands that go beyond facilitating capitalist accumulation.

\section{Conclusion}

The peculiar commodity represented by tourism attractions and the ways China's institutions channel the productivist, environmental, and social logics infusing protected area management propel tourism dynamos. Access to scenery can be commodified because land in protected areas is withheld from market exchange: reservation bolsters selective commodification. With access to its own investment capital and control over local parks, the local state can make park tourism generate revenues for local projects. Meanwhile, facing pressure to maintain social stability, local authorities make varied efforts to incorporate residents. The tourism dynamo provides a 
counterpoint to narratives of pervasive neoliberal conservation. With respect to China, it also provides a picture of land-based intensification that urban-centered scholarship has overlooked.

In China, relative to other rural development strategies, tourism is especially conducive to such dynamos. Resource-based rural sectors like mining and hydropower are dominated by central planning and national state-owned enterprises (See Woodworth, this issue). Tourism development, in contrast, offers local governments much greater room to manage operations and extract revenue. Direct authority over protected areas and access to financing platforms enables local governments to effect far-reaching transformations. Similar dynamics appear around "dragon-head" enterprises established to process agricultural products and coordinate cash crop production (Lingohr-Wolf, 2011). But the necessity of working through collectives and households to aggregate land and coordinate production makes the process messier. Crosssector comparative research may provide insights into the capacities and motivations of local states, especially in regions where tourism coexists with mining and hydropower development.

This synthesis of productivist and environmental logics promises a synergy among conservation, economic growth, and social welfare. However, without a realignment of interests, tourism intensification is unlikely to bring either greater participation by residents or more effective conservation management. China's central government has shown concern about overexpansion of tourism at premiere attractions, but it will be hard pressed to eliminate a phenomenon that it simultaneously supports through high-powered incentives exerted through an entrenched institutional complex built around tourism development. In contrast to a fully privatized tourism industry, state-managed tourism does have the advantage of affording direct channels for regulation should state agencies give social and environmental priorities greater 
precedence. However, the forces that propel local state tourism dynamos have gathered great momentum and will not easily be turned aside.

These findings not only illuminate the processes recasting remote locales across China, but draw our attention back to the role of the state in mediating market-based conservation everywhere. In the vast majority of protected areas, the state mediates access for tourism. China's political economy yields a particular pattern of tourism intensification. Across space and time we may find a spectrum of conjunctures as states, firms, and residents confront the peculiar commodity of the nature tourism attraction within different histories and institutions.

\section{Bibliography}

Aba Prefecture People's Government, 2006. Opinions of the Aba Prefecture People's Government on Strengthening Ticket Revenue Management at Jiuzhaigou and Huanglong Attractions (in Chinese).

Adams, W.M., 2004. Against Extinction. Earthscan, London.

Albers, H.J., Grinspoon, E., 1997. A Comparison of the Enforcement of Access Restrictions Between Xishuangbanna Nature Reserve (China) and Khao Yai National Park (Thailand). Environmental Conservation 24, 351-362.

Anagnost, A., 2004. The Corporeal Politics of Quality (Suzhi). Public Culture 16, 189-208.

Author, 2013. Dissertation.

Bakker, K., 2010. The Limits of "Neoliberal Natures": Debating Green Neoliberalism. Progress in Human Geography 34, 715-735. doi:10.1177/0309132510376849

Balmford, A., Beresford, J., Green, J., Naidoo, R., Walpole, M., Manica, A., 2009. A Global Perspective on Trends in Nature-Based Tourism. PLoS Biology 7, e1000144. doi:10.1371/journal.pbio.1000144

Boyd, W., Prudham, W.S., Schurman, R.A., 2001. Industrial Dynamics and the Problem of Nature. Society \& Natural Resources 14, 555-570. doi:10.1080/08941920120686

Brandon, K., Redford, K.H., Sanderson, S.E. (Eds.), 1998. Parks in Peril: People, Politics, and Protected Areas. The Nature Conservancy, Washington, D.C.

Brenner, N., Peck, J., Theodore, N., 2010. Variegated Neoliberalization: Geographies, Modalities, Pathways. Global Networks 10, 182-222. doi:10.1111/j.1471-0374.2009.00277.x

Brockington, D., 2002. Fortress Conservation: The Preservation of the Mkomazi Game Reserve, Tanzania. Indiana University Press, Bloomington. 
Brockington, D., Duffy, R., 2010. Capitalism and Conservation: The Production and Reproduction of Biodiversity Conservation. Antipode 42, 469-484. doi:10.1111/j.14678330.2010.00760.x

Büscher, B., Sullivan, S., Neves, K., Igoe, J., Brockington, D., 2012. Towards a Synthesized Critique of Neoliberal Biodiversity Conservation. Capitalism Nature Socialism 23, 4-30. doi:10.1080/10455752.2012.674149

Bushell, R., Staiff, R., Eagles, P.F.J., 2007. Tourism and Protected Areas: Benefits Beyond Boundaries, in: Bushell, R., Eagles, P.F.J. (Eds.), Tourism and Protected Areas: Benefits Beyond Boundaries. CABI, Wallingford, UK, pp. 1-11.

Butt, B., 2012. Commoditizing the Safari and Making Space for Conflict: Place, Identity and Parks in East Africa. Political Geography 31, 104-113. doi:10.1016/j.polgeo.2011.11.002

Central Committee of the Communist Party of China, 2013. The Decision on Major Issues Concerning Comprehensively Deepening Reforms (in Chinese).

Charmaz, K., 2006. Constructing Grounded Theory: A Practical Guide Through Qualitative Analysis. SAGE, London.

Chen, J.C., 2015 Consent to Environmentalization and Shifting Rural Administrative Authority in Contemporary China. Geoforum.

Chio, J., 2014. A Landscape of Travel: The Work of Tourism in Rural Ethnic China. University of Washington Press, Seattle.

Christ, C., Hillel, O., Matus, S., Sweeting, J., 2003. Tourism and Biodiversity: Mapping Tourism's Global Footprint. Conservation International, Washington, D.C.

Diqing Prefecture Tourism Development Investment Company, 2010. Public Record of Diqing Prefecture Tourism Development Investment Company. URL http:/ / www.stats.yn.gov.cn/canton_model17/newsview.aspx?id=1195623 (accessed 10.21.11) (in Chinese).

Donaldson, J.A., 2007. Tourism, Development and Poverty Reduction in Guizhou and Yunnan. The China Quarterly 190, 333-351. doi:10.1017/S0305741007001221

Dressler, W., Büscher, B., 2008. Market Triumphalism and the CBNRM "Crises" at the South African Section of the Great Limpopo Transfrontier Park. Geoforum 39, 452-465. doi:10.1016/j.geoforum.2007.09.005

Dressler, W., Roth, R., 2011. The Good, the Bad, and the Contradictory: Neoliberal Conservation Governance in Rural Southeast Asia. World Development 39, 851-862. doi:10.1016/j.worlddev.2010.08.016

Evans, P.B., 1995. Embedded Autonomy: States and Industrial Transformation. Princeton University Press, Princeton.

Feng, X., 2008. Who Benefits?: Tourism Development in Fenghuang County, China. Human Organization 67, 207-220.

Greenhalgh, S., Winckler, E.A., 2005. Governing China's Population: From Leninist to Neoliberal Biopolitics. Stanford University Press, Stanford.

Han, N., Zhuge, R., 2001. Ecotourism in China's Nature Reserves: Opportunities and Challenges. Journal of Sustainable Tourism 9, 228-242. doi:10.1080/09669580108667400

Harris, R.B., 2008. Wildlife Conservation in China. M.E. Sharpe, Armonk, NY.

Harvey, D., 2005. A Brief History of Neoliberalism. Oxford University Press, New York.

Hathaway, M., 2014. Wild Commodities and Environmental Governance: Transforming Lives and Markets in China and Japan. Conservation and Society 12, 398-407. doi:10.4103/09724923.155583 
Herrold-Menzies, M., 2006. Integrating Conservation and Development: What We Can Learn From Caohai, China. The Journal of Environment \& Development 15, 382-406.

Ho, S.P.S., Lin, G.C.S., 2003. Emerging Land Markets in Rural and Urban China: Policies and Practices. The China Quarterly 175, 681-707. doi:10.1017/S0305741003000407

Hou Q., 2013. Sixty Years of Transformation in Jiuzhaigou County: The Successful Transition from "Timber Finance" to "Tourism Finance". Sichuan News Net (in Chinese).

Huang S., Gu M., 2014. Yangjiajie Cablecar in Zhangjiajie Begins Provisional Operation. Ta Kung Pao. http:/ / finance.takungpao.com/q/2014/0211/2270693.html (in Chinese).

Igoe, J., Brockington, D., 2007. Neoliberal Conservation: A Brief Introduction. Conservation and Society 5, 432-449.

Igoe, J., Neves, K., Brockington, D., 2010. A Spectacular Eco-Tour around the Historic Bloc: Theorising the Convergence of Biodiversity Conservation and Capitalist Expansion. Antipode 42, 486-512. doi:10.1111/j.1467-8330.2010.00761.x

Kang, X., 2009. Two Temples, Three Religions, and a Tourist Attraction: Contesting Sacred Space on China's Ethnic Frontier. Modern China 35, 227-255. doi:10.1177/0097700408329600

Karanth, K.K., DeFries, R., 2011. Nature-Based Tourism in Indian Protected Areas: New Challenges for Park Management. Conservation Letters 4, 137-149. doi:10.1111/j.1755263X.2010.00154.x

Kelly, A.B., 2011. Conservation Practice as Primitive Accumulation. Journal of Peasant Studies 38, 683-701. doi:10.1080/03066150.2011.607695

King, D.A., Stewart, W.P., 1996. Ecotourism and Commodification: Protecting People and Places. Biodiversity and Conservation 5, 293-305. doi:10.1007/BF00051775

Kingfisher, C., Maskovsky, J., 2008. Introduction: The Limits of Neoliberalism. Critique of Anthropology 28, 115-126. doi:10.1177/0308275X08090544

Kipnis, A., 2007. Neoliberalism Reified: Suzhi Discourse and Tropes of Neoliberalism in the People's Republic of China. Journal of the Royal Anthropological Institute 13, 383-400. doi:10.1111/j.1467-9655.2007.00432.x

Kirkby, C.A., Giudice, R., Day, B., Turner, K., Soares-Filho, B.S., Oliveira-Rodrigues, H., Yu, D.W., 2011. Closing the Ecotourism-Conservation Loop in the Peruvian Amazon. Environmental Conservation 38, 6-17. doi:10.1017/S0376892911000099

Klooster, D., 2006. Environmental Certification of Forests in Mexico: The Political Ecology of a Nongovernmental Market Intervention. Annals of the Association of American Geographers 96, 541-565. doi:10.2307/4124432

Kohli, A., 1994. Where Do High Growth Political Economies Come From? The Japanese Lineage of Korea's “Developmental State." World Development 22, 1269-1293. doi:10.1016/0305750X(94)90004-3

Lee, C.K., Zhang, Y., 2013. The Power of Instability: Unraveling the Microfoundations of Bargained Authoritarianism in China. American Journal of Sociology 118, 1475-1508. doi:10.1086/670802

Lele, S., Wilshusen, P., Brockington, D., Seidler, R., Bawa, K., 2010. Beyond Exclusion: Alternative Approaches to Biodiversity Conservation in the Developing Tropics. Current Opinion in Environmental Sustainability 2, 94-100.

Lingohr-Wolf, S., 2011. Industrialisation and Rural Livelihoods in China: Agricultural Processing in Sichuan. Routledge, New York.

Li, T.M., 2008. Contested Commodifications: Struggles over Nature in a National Park, in: Nevins, J., Peluso, N.L. (Eds.), Taking Southeast Asia to Market : Commodities, Nature, and People in the Neoliberal Age. Cornell University Press, Ithaca, pp. 124-139. 
Li, W., Zhang, Q., Liu, C., Xue, Q., 2006. Tourism's Impacts on Natural Resources: A Positive Case from China. Environmental Management 38, 572-579. doi:10.1007/s00267-004-0299-z

Li, Y., Li, W., Zhang, C., Fan, M., 2013. Current Status and Recent Trends in Financing China's Nature Reserves. Biological Conservation 158, 296-300. doi:10.1016/j.biocon.2012.10.005

Logan, J.R., Molotch, H.L., 2007. Urban Fortunes: The Political Economy of Place, 2nd ed. University of California Press, Berkeley.

Ma, X., 2009. Summary of the Ten-Year Periodic Assessment of Jiuzhaigou World Biosphere Reserve. Man and Biosphere Bulletin 103, 1-4.

MacCannell, D., 1989. The Tourist: A New Theory of the Leisure Class, Rev. ed. Schocken Books, New York.

Machlis, G.E., Field, D.R. (Eds.), 2000. National Parks and Rural Development: Practice and Policy in the United States. Island Press, Washington, D.C. and Covelo, CA.

McAfee, K., Shapiro, E.N., 2010. Payments for Ecosystem Services in Mexico: Nature, Neoliberalism, Social Movements, and the State. Annals of the Association of American Geographers 100, 579-599. doi:10.1080/00045601003794833

McCarthy, J., 2005. Devolution in the Woods: Community Forestry as Hybrid Neoliberalism. Environment and Planning A 37, 995 - 1014. doi:10.1068/a36266

McCarthy, J., Prudham, S., 2004. Neoliberal nature and the nature of neoliberalism. Geoforum, Themed issue on "Neoliberal nature and the nature of neoliberalism" 35, 275-283. doi:10.1016/j.geoforum.2003.07.003

McElwee, P.D., 2012. Payments for Environmental Services as Neoliberal Market-Based Forest Conservation in Vietnam: Panacea or Problem? Geoforum 43, 412-426. doi:10.1016/j.geoforum.2011.04.010

Molotch, H., 1993. The Political Economy of Growth Machines. Journal of Urban Affairs 15, 2953. doi:10.1111/j.1467-9906.1993.tb00301.x

Naughton-Treves, L., Buck Holland, M., Brandon, K., 2005. The Role of Protected Areas in Conserving Biodiversity and Sustaining Local Livelihoods. Annual Review of Environment and Resources 30, 219-252.

Neumann, R.P., 2004. Moral and Discursive Geographies in the War for Biodiversity in Africa. Political Geography 23, 813-837. doi:10.1016/j.polgeo.2004.05.011

Nonini, D.M., 2008. Is China Becoming Neoliberal? Critique of Anthropology 28, 145-176. doi:10.1177/0308275X08091364

Nyíri, P., 2006. Scenic Spots: Chinese Tourism, the State, and Cultural Authority. University of Washington Press, Seattle.

Oakes, T., 1998. Tourism and Modernity in China. Routledge, London.

Oakes, T., 2006. Cultural Strategies of Development: Implications for Village Governance in China. Pacific Review 19, 13-37. doi:10.1080/09512740500417616

Ohl-Schacherer, J., Mannigel, E., Kirkby, C., Shepard, Jr., G.H., Yu, D.W., 2008. Indigenous Ecotourism in the Amazon: A Case Study of "Casa Matsiguenka" in Manu National Park, Peru. Environmental Conservation 35, 14-25.

Ong, A., 2007. Neoliberalism as a Mobile Technology. Transactions of the Institute of British Geographers 32, 3-8. doi:10.1111/j.1475-5661.2007.00234.x

Peck, J., Tickell, A., 2002. Neoliberalizing Space. Antipode 34, 380-404. doi:10.1111/14678330.00247

Peluso, N.L., 1992. Rich Forests, Poor People: Resource Control and Resistance in Java. University of California Press, Berkeley. 
Pfeffer, M.J., Schelhas, J.W., Meola, C., 2006. Environmental Globalization, Organizational Form, and Expected Benefits from Protected Areas in Central America. Rural Sociology 71, 429450.

Qin, Q., Wall, G., Liu, X., 2011. Government Roles in Stimulating Tourism Development: A Case from Guangxi, China. Asia Pacific Journal of Tourism Research 16, 471-487. doi:10.1080/10941665.2011.597573

Quan, J., Ouyang, Z., Xu, W., Miao, H., 2011. Assessment of the effectiveness of nature reserve management in China. Biodiversity and Conservation 20, 779-792. doi:10.1007/s10531-0109978-7

Ribot, J.C., Lund, J.F., Treue, T., 2010. Democratic decentralization in sub-Saharan Africa: its contribution to forest management, livelihoods, and enfranchisement. Environmental Conservation 37, 35-44. doi:10.1017/S0376892910000329

Robertson, M.M., 2004. The Neoliberalization of Ecosystem Services: Wetland Mitigation Banking and Problems in Environmental Governance. Geoforum 35, 361-373. doi:10.1016/j.geoforum.2003.06.002

Sellars, R.W., 2009. Preserving Nature in the National Parks: A History, 2nd ed. Yale University Press, New Haven.

Smith, G., 2010. The Hollow State: Rural Governance in China. The China Quarterly 203, 601618. doi:10.1017/S0305741010000615

Smith, G., 2013. Measurement, Promotions and Patterns of Behavior in Chinese Local Government. Journal of Peasant Studies 40, 1027-1050. doi:10.1080/03066150.2013.866095

So, A.Y., Chu, Y., 2012. The Transition from Neoliberalism to State Neoliberalism in China at the Turn of the Twenty-Fist Century, in: Chang, K.-S., Fine, B., Weiss, L. (Eds.), Developmental Politics in Transition: The Neoliberal Era and Beyond. Palgrave Macmillan, New York.

State Council (State Council of the People's Republic of China), 1994. Regulations on Nature Reserves (in Chinese).

$\mathrm{Su}, \mathrm{X} ., 2010$. Urban conservation in Lijiang, China: Power structure and funding systems. Cities 27, 164-171. doi:10.1016/j.cities.2009.12.004

Tao, R., Su, F., Liu, M., Cao, G., 2010. Land Leasing and Local Public Finance in China's Regional Development: Evidence from Prefecture-level Cities. Urban Stud 47, 2217-2236. doi:10.1177/0042098009357961

Tian, S., 2010. Research on the Management Model of Jiuzhaigou Scenic Area (Ph.D. Dissertation). Yunnan University, Kunming (in Chinese).

Tian, S., Yang, G., 2009. An Empirical Study on the Changes in Management Systems of National Parks —A Case Study of Pudatsuo National Park in Shangri-la of Yunnan Province. Journal of Guangxi University for Nationalities (Philosophy and Social Science Edition) 31, 52-57 (in Chinese).

Tsui, K., 2011. China's Infrastructure Investment Boom and Local Debt Crisis. Eurasian Geography and Economics 52, 686-711. doi:10.2747/1539-7216.52.5.686

Urgenson, L., Schmidt, A.H., Combs, J., Harrell, S., Hinckley, T., Yang, Q., Ma, Z., Yongxian, L., Hongliang, L., MacIver, A., 2014. Traditional Livelihoods, Conservation and Meadow Ecology in Jiuzhaigou National Park, Sichuan, China. Human Ecology 42, 481-491. doi:10.1007/s10745-014-9650-z

Vaughan, A., 2014. Ecuador signs permits for oil drilling in Amazon's Yasuni national park. The Guardian. URL http://www.theguardian.com/environment/2014/may/23/ecuadoramazon-yasuni-national-park-oil-drill (accessed 7.31.15). 
Wang, C., Ou, S., Wu, W., 2010. Probe into Eco-environmental Monitoring System in Zhangjiajie National Forest Park. Issues in Forestry Economics 30, 435-438 (in Chinese).

Wang, C., Wu, W., Cheng, F., 2009. Probe on Ecological Security Management Model of Zhangjiajie National Forest Park. Economic Geography 29, 1580-1584 (in Chinese).

Wang, G., Innes, J.L., Wu, S.W., Krzyzanowski, J., Yin, Y., Dai, S., Zhang, X., Liu, S., 2011. National Park Development in China: Conservation or Commercialization? Ambio 41, 247261. doi:10.1007/s13280-011-0194-9

Wang, Y., Bramwell, B., 2012. Heritage Protection and Tourism Development Priorities in Hangzhou, China: A Political Economy and Governance Perspective. Tourism Management 33, 988-998. doi:10.1016/j.tourman.2011.10.010

Weckerle, C.S., Yang, Y., Huber, F.K., Li, Q., 2010. People, Money, and Protected Areas: the Collection of the Caterpillar Mushroom Ophiocordyceps sinensis in the Baima Xueshan Nature Reserve, Southwest China. Biodiversity and Conservation 19, 2685-2698. doi:10.1007/s10531-010-9867-0

West, P., Carrier, J.G., 2004. Ecotourism and Authenticity: Getting Away from It All? Current Anthropology 45, 483-498.

West, P., Igoe, J., Brockington, D., 2006. Parks and Peoples: The Social Impact of Protected Areas. Annual Review of Anthropology 35, 251-277.

Whiting, S.H., 2004. The Cadre Evaluation System at the Grassroots: The Paradox of Party Rule, in: Naughton, B., Yang, D. (Eds.), Holding China Together: Diversity and National Integration in the Post-Deng Era. Cambridge University Press, Cambridge, pp. 101-119.

Wilshusen, P.R., Brechin, S.R., Fortwangler, C.L., West, P.C., 2002. Reinventing a Square Wheel: Critique of a Resurgent "Protection Paradigm" in International Biodiversity Conservation. Society and Natural Resources 15, 17-40.

Woo-Cumings, M. (Ed.), 1999. The Developmental State. Cornell University Press, Ithaca, N.Y. Woodworth, M., 2015. Disposable Ordos: Mining, urban growth, and the development of China's west from a commodity frontier perspective. Geoforum.

Wu, F., 2008. China's Great Transformation: Neoliberalization as Establishing a Market Society. Geoforum 39, 1093-1096. doi:10.1016/j.geoforum.2008.01.007

Wu Guanzhong, 1980. Unknown to Any, a Beauty Hidden [WWW Document]. People.com.cn. URL http:/ / blog.people.com.cn/article/2/1336945671479.html (accessed 1.17.15) (in Chinese).

Wulingyuan Scenic Resort Administrative Department, 2002. The State of Conservation of the World Natural Heritage: Wulingyuan.

Xiang, Z., Yu, Y., Yang, M., Yang, J., Niao, M., Li, M., 2011. Does flagship species tourism benefit conservation? A case study of the golden snub-nosed monkey in Shennongjia National Nature Reserve. China Science Bulletin 56, 2553-2558. doi:10.1007/s11434-011-4613-x

Xie, Y., Wang, S., Schei, P. (Eds.), 2004. China's Protected Areas. Tsinghua University Press, Beijing.

Xu, J., Melick, D.R., 2007. Rethinking the Effectiveness of Public Protected Areas in Southwestern China. Conservation Biology 21, 318-328. doi:10.1111/j.15231739.2006.00636.x

Xu, J., Yeh, A., Wu, F., 2009. Land Commodification: New Land Development and Politics in China since the Late 1990s. International Journal of Urban and Regional Research 33, 890 913. doi:10.1111/j.1468-2427.2009.00892.x 
Xu, J., Zhang, Z., Liu, W., McGowan, P.J.K., 2012. A Review and Assessment of Nature Reserve Policy in China: Advances, Challenges and Opportunities. Oryx 46, 554-562. doi:10.1017/S0030605311000810

Yan, H., 2003. Neoliberal Governmentality and Neohumanism: Organizing Suzhi/Value Flow through Labor Recruitment Networks. Cultural Anthropology 18, 493-523.

Ye, W., Shen, C., Li, Y., 2008. The Eyes of Shangri-la: Planning and Construction of Putatso National Park. China Environmental Science Publisher, Beijing (in Chinese).

Yeh, E.T., 2009. Greening Western China: A Critical View. Geoforum 40, 884-894. doi:10.1016/j.geoforum.2009.06.004

Yeh, E.T., 2013. The Politics of Conservation in Contemporary Rural China. Journal of Peasant Studies 40, 1165-1188. doi:10.1080/03066150.2013.859575

Yunnan Provincial Committee of the CPC, Provincial Government of Yunnan, 2004. Some Opinions of the Yunnan Province Committee of the Communist Party of China and the Provincial Government of Yunnan on Further Accelerating the Development of the Tourism Sector, in: Luo Mingyi, Yuan Guanghan, Cen Shuyun (Eds.), The Second Phase of Innovation in Tourism in Yunnan: Development Strategies and Plans. Yunnan University Press, Kunming, pp. 3-12 (in Chinese).

Zeng, B., Ryan, C., 2012. Assisting the Poor in China through Tourism Development: A Review of Research. Tourism Management 33, 239-248.

Zhang C., Xu H., 2007. Change in Management Models for China's World Natural Heritage Resources: A Case Study of Wulingyuan. Management World 52-65 (in Chinese).

Zhang, Q., 2014. China will Build a National Park System to Protect the Environment. ScienceNet.cn (in Chinese).

Zhang, Q.F., Wu, J., 2015. Constructing 'New Rural Communities' in Chengdu, China: Commodifying Land and Contesting Rural Spatiality. Geoforum.

Zhang, Y., 2008. Steering towards growth: Symbolic urban preservation in Beijing, 1990-2005. Town Planning Review 79, 187-208. doi:10.3828/tpr.79.2-3.3

Zhangjiajie Municipality People's Government, 2011. Zhangjiajie National Forest Park Delivers on "Benefit the People Program". Zhangjiajie Tourism Administrative Website. URL http:/ / www.zhangjiajie.gov.cn/html/15/n_1915.html (accessed 7.16.12) (in Chinese).

Zhangjiajie Tourism Group, 2014. 2013 Annual Report. Zhangjiajie Municipality (in Chinese).

Zhong, L., Deng, J., Xiang, B., 2008. Tourism Development and the Tourism Area Life-Cycle Model: A Case Study of Zhangjiajie National Forest Park, China. Tourism Management 29, 841-856. doi:10.1016/j.tourman.2007.10.002

Zhou, D.Q., Grumbine, R.E., 2011. National Parks in China: Experiments with Protecting Nature and Human Livelihoods in Yunnan Province, Peoples' Republic of China (PRC). Biological Conservation 144, 1314-1321. doi:10.1016/j.biocon.2011.01.002

Zhuang, B., Huang, D., 2011. Visitation to Nation's Forest Parks in 2010 Surpassed 396 Million. Xinhua Net. http://www.hainan.news.cn/focus/2011-11/17/content_24148618.htm (in Chinese).

Zhuang Y., Xu R., Yang R., Xu X., 2012. A Discussion of Sustainable Development of Tourism in Jiuzhaigou World Heritage Site. 78-81 (in Chinese).

Zinda, J.A., 2012. Hazards of Collaboration: Local State Co-optation of a New Protected-Area Model in Southwest China. Society \& Natural Resources 25, 384-399. doi:10.1080/08941920.2011.557826 
Zinda, J.A., 2014. Making National Parks in Yunnan: Shifts and Struggles within the Ecological State, in: Yeh, E.T., Coggins, C.R. (Eds.), Mapping Shangrila: Nature, Personhood and Polity in the Sino-Tibetan Borderlands. University of Washington Press, Seattle, pp. 105-128. 


\section{Acknowledgments}

I thank Gary Green, Michael Dougherty, Emily Yeh, Siri Veland, Jia-Ching Chen, John Logan, several anonymous reviewers, and participants in the Recasting the Rural workshop at Brown University for reading drafts and offering challenging feedback. I surely have not fully realized the insights contained in their suggestions, and any errors in this piece are my own. This material is based upon work supported by the National Science Foundation under Grant No. DGE-0549369 IGERT: Training Program on Biodiversity Conservation and Sustainable Development in Southwest China at the University of Wisconsin-Madison and by a dissertation research award from the Rural Sociological Society. 